\title{
DESIGN AND DETERMINATION OF THE EFFICIENCY OF A SLANTING-TYPE SOLAR WATER DISTILLATION KIT
}

\author{
J. 0. Ozuomba ${ }^{1, *}$, A. Emmanuel 2 , C. U. Ozuomba ${ }^{3}$ and M. C. Udoye ${ }^{4}$ \\ 1,2DEPARTMENT OF Physics, FACUlty OF SCIENCE, IMO STATE UNIVERSITY, OWERri, IMO STATE. NIGERIA. \\ 3DEPARTMENT OF ARChiteCtURE, CARITAS UniVERSity, ENUGU, ENUGU STATE, NIGERIA.

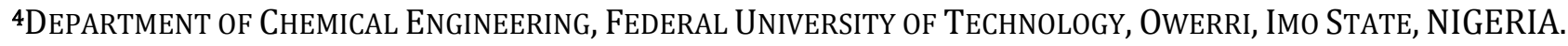 \\ E-mail addresses:1 okanduj@gmail.com, 2 kukuri2004@yahoo.com, 3 ozuocornelu@gmail.com, \\ 4 chiamakaudoye5@yahoo.com
}

\begin{abstract}
The solar water distillation system is a non-toxic and promising device for water purification. A slanting-type solar water distillation kit was fabricated and tested outdoor under the meteorological conditions of Imo State University, Owerri, Nigeria. The system consists of four major components; a wooden basin of surface area $0.16 \mathrm{~m}^{2}$, an absorber surface, a slanting glass roof and a condensate channel. Locally available materials were used to fabricate the solar still. The solar still produced an average of $0.09 \mathrm{~m}^{3}$ of distilled water per day, and this study was performed in the month of November, 2015. Daily efficiencies of the distillation kit were estimated and the average efficiency of the kit was found to be 7.7\%. Though the efficiency is small as is peculiar to many solar systems, the output can be increased by increasing some parameters like the surface area, slanting angle of the roof, and the evaporation rate. Also, since the materials are readily available, one can fabricate as many solar distillation kits as possible to tackle the daily demand of potable water. Solar distillation kits can also serve as sources of distilled water for our hospitals and industries.
\end{abstract}

Keywords: Imo State, potable water, solar still efficiency, water distillation, water purification.

\section{INTRODUCTION}

There is almost no water left on Earth that is safe to drink without purification [1]. Solar distillation is possibly the oldest method of desalination of water [2]. Its principle of operation is the greenhouse effect; the radiation from the sun evaporates water inside a closed glass covered chamber at a temperature higher than the ambient. Most of our earth surface is covered with water; however, less than $1 \%$ of total available water is fresh water which is most available in lakes, rivers and underground reserves [1, 2]. Natural surface water bodies like rivers and streams are subjected to pollution comprising of organic and inorganic constituents [3-6]. The problems of ground water quality are much more acute in the areas which are densely populated, thickly industrialized and have shallow groundwater tables [7, 8]. The rapid growth of urban areas in Nigeria has affected surface and ground water quality due to over exploitation of resources and improper waste disposal practices [3]. Water is extremely essential for survival of all living organisms. Over one billion people worldwide have no access to safe drinking water [7-9]. Ideally, drinking water should not contain any microorganism known to be pathogenic or any bacteria indicative of faecal pollution [9]. Water that is free of salinity, organic and inorganic substances, chlorination by-products, free of plants, animal wastes and bacteria contamination is known as potable water [10-12].

Solar distillation is a process where solar energy is used to produce fresh water for drinking, domestic and other purposes. Convention water purification processes such as multi-effect fresh evaporation, thin film distillation, reverse osmosis and electro dialysis are energy intensive techniques and are not feasible for large fresh water demands [12]. Therefore, solar distillation seems to be a promising method and an alternative method for providing safe drinking water. Solar distillation is a highly promising and environment friendly technology [2, 8, 13-15]. A solar still operates on the same principle as that of rain formation: water from the ocean evaporates, then cools, condenses, and returns to earth as rainwater $[2,6,16]$. When water evaporates, only pure water vapour is formed while contaminants are left behind in the still basin and the distillate flows to the collection gutter by gravity. Among the many factors considered in the design and fabrication of a solar water distillation system are cost implication and efficiency. As a supporting technique for water purification, various 
types of solar stills have been developed and are being applied worldwide [1,17-19]. The summary of different classes of solar distillation systems is shown in Figure 1 [2]. Solar stills can be easily constructed from local materials and can be managed by unskilled personnel. Generally, solar still systems have the advantage of low operating and maintenance costs and the shortcoming of low thermal efficiencies [7, 19, 20].

The present study was undertaken to design and investigate the performance of a slanting-type solar water distillation (SSWD) kit. The SSWD system, which replicates the natural process of evaporation and condensation was fabricated from cheap and local materials. A wooden box covered with black polyethylene absorber surface formed the water heating chamber or water basin. The water basin has a slanting top onto which a glass sheet was gently placed to form the glass roof. Beneath the glass roof was a gutter or condensate channel for driving out distilled water. The heating and evaporation took place on the absorber surface, while condensing process took place on the glass roof. The water sample was collected from Njaba River and the variation of the ambient and internal temperatures of still was studied. Also, the efficiency of the solar distillation kit was estimated. The characterization of our distillation kit was carried out in the month of November, 2015 under the actual environmental conditions of Imo State University, Owerri, Nigeria.

\section{MATERIALS AND METHODS}

A schematic diagram of an SSWD system whose interior has been covered with black polyethylene is shown in Figure 2.The water basin which also functions as the heating chamber has a surface area of $0.16 \mathrm{~m}^{2}$. A glass sheet of length $76.0 \mathrm{~cm}$ and width $38.2 \mathrm{~cm}$ was gently placed on the slanting surface of the water tank to obtain the glass roof. The water tap can be used to discharge untreated water sample.

Figure 3 shows the inlet for impure water, the outlet for distilled water and the SSWD stand of height $69.5 \mathrm{~cm}$. The condensate channel was made of aluminium sheets, while the wooden frame that formed the water basin also served as thermal insulator. A piece of black leather was used to cover the edges of the glass roof to avoid contaminants like rain water which may drip into the condensation channel. The parameters of the solar still are given in Table 1.

Table 1. Design parameters of the SSWD kit

\begin{tabular}{ll}
\hline \multicolumn{1}{c}{ Parameter } & \multicolumn{1}{c}{ Value } \\
\hline Area of collecting surface & $0.16 \mathrm{~m}^{2}$ \\
Area of basin & $0.16 \mathrm{~m}^{2}$ \\
Tilt angle of glass roof & $23^{0}$ \\
Thickness of glass cover & $0.003 \mathrm{~m}$ \\
Height of back wall of basin & $0.398 \mathrm{~m}$ \\
Height of front wall of basin & $0.245 \mathrm{~m}$ \\
Width of basin & $0.360 \mathrm{~m}$ \\
Height of tank stand & $0.695 \mathrm{~m}$ \\
Thickness of black polyethylene & $0.0006 \mathrm{~m}$ \\
\hline
\end{tabular}

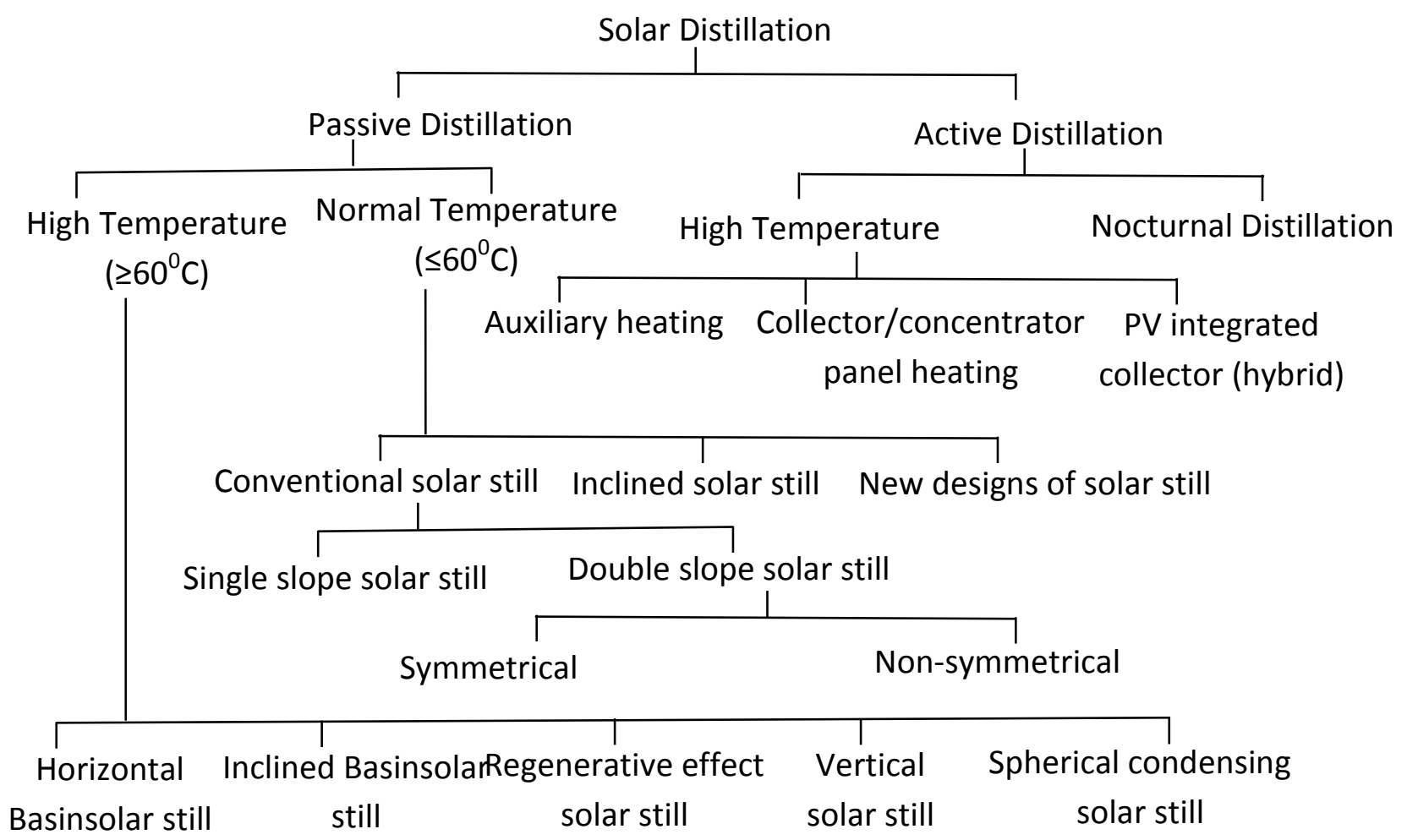

Figure 1: Classification of solar distillation systems [2] 


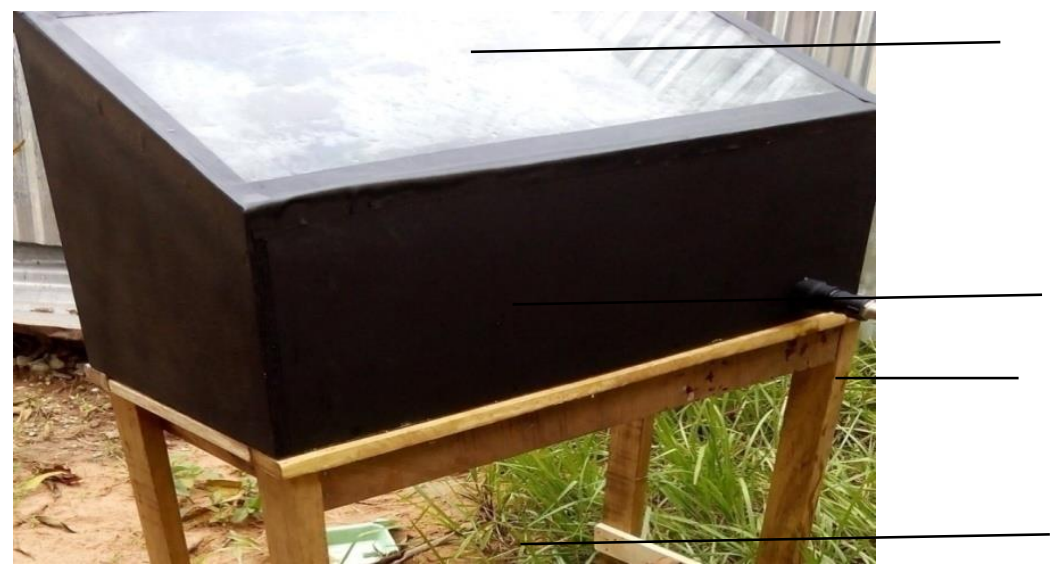

Slanting glass roof

Water tank

Water tap

Solar still stand

Figure 2: Isometric view of the slanting-type solar water distillation (SSWD) kit

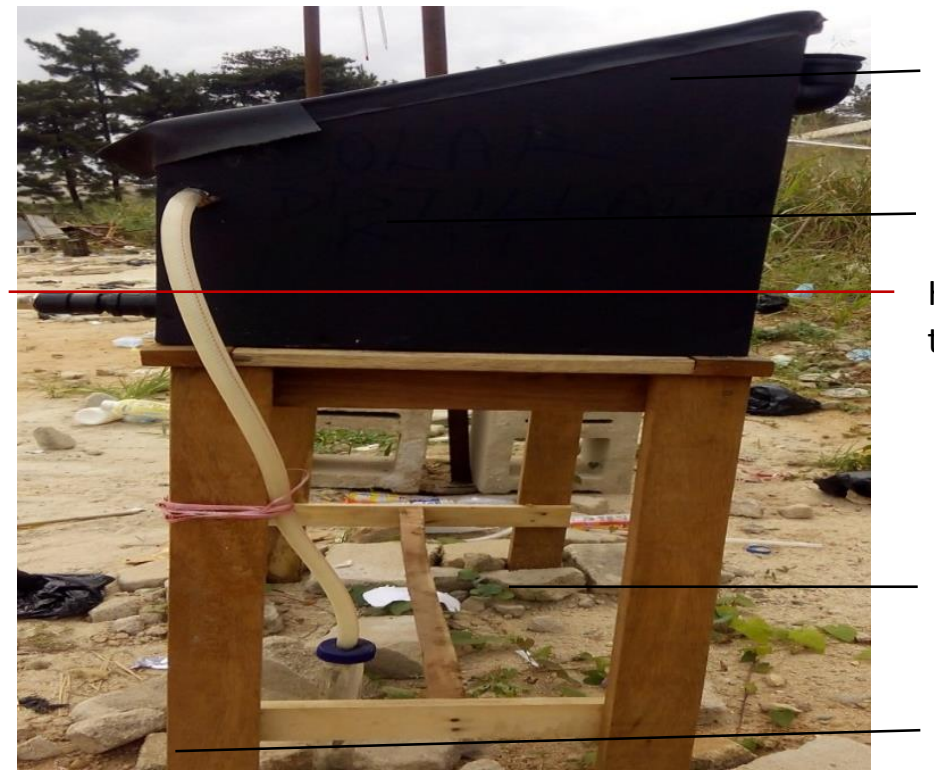

Inlet for impure water

\section{Water tank}

Hose pipe connected through the condensate channel

Solar still stand

Figure 3: Side view of the slanting-type solar water distillation (SSWD) kit

Incident solar radiation passes through the glass cover and is mostly absorbed by the blackened liner of the basin. The untreated water begins to heat up and the moisture content of the air trapped between the water surface and the glass cover increases. The heated water evaporates from the basin and condenses on the inside of the glass cover. Condensed water trickles down the inclined glass cover to the interior collection trough and out through a hose pipe to a storage bottle.

The volume of distilled water produced hourly by the SSWD kit was measured for seven consecutive days. The water sample was obtained from the Awomamma Station of Njaba River. Njaba River is located in the Eastern part of Nigeria. Hourly measurement of volume and temperature was carried out for seven days (from 8am to $6 \mathrm{pm}$ ) at Imo State University, Owerri, Nigeria. The hourly ambient temperature $\left(\mathrm{T}_{\text {ext }}\right)$ was measured using a copper/constantan thermocouple. The corresponding internal temperature $\left(\mathrm{T}_{\text {int }}\right)$ of the SSWD kit was also obtained. The efficiency ( $\eta$ ) of the slanting-type solar water distillation kit was calculated using the energy method [6].

$$
\eta=\frac{A P H}{3600 G}
$$

In (1), $P$ is the daily production, $H$ is the latent heat of vaporization, $A$ is the collecting area and $G$ is the daily total insolation.

\section{RESULTS AND DISCUSSION}

The variation of the ambient temperature with the internal temperature of the SSWD for the fourth day is shown in Figure 4. This figure represents the general behavior of temperature variation for the distillation kit. The values of the internal temperature of the still are always higher than the ambient temperature, with high temperatures differences recorded between $11 \mathrm{am}$ and $3 \mathrm{pm}$. This is an evidence of the effect of the heating chamber (water tank) and the absorber surface (black liner). The values of external and internal temperatures were almost the same at dawn and this phenomenon also repeated itself at dusk. Meanwhile, as incident solar 
radiation increases, the internal temperature increases correspondingly by an appreciable high margin.

The nature of solar parameters within the seven days of the diurnal survey is represented in Table 2. are shown in Table 2. The Table consists of five solar parameters; the average ambient temperature (Textav), average internal temperature (Tintav), maximum ambient temperature (Textmax), maximum internal temperature (Tintmax) and maximum temperature difference (Tdfmax). The temperature difference was found by subtracting the hourly external (ambient) temperature from the hourly internal temperature. All temperature values were measured in Degrees Centigrade. The highest value of internal temperature recorded was $58^{\circ} \mathrm{C}$ when the external temperature was $36^{\circ} \mathrm{C}$. This occurred on the fourth day by $2 \mathrm{pm}$. Also the highest temperature difference of $22^{\circ} \mathrm{C}$ was recorded on Day 1 by 12 noon and on Day 4 by $2 \mathrm{pm}$.

Table 2. Survey of some solar parameters

\begin{tabular}{cccccc}
\hline Days & $\begin{array}{c}\text { Textav } \\
\left({ }^{\circ} \mathrm{C}\right)\end{array}$ & $\begin{array}{c}\text { Tintav } \\
\left({ }^{\circ} \mathrm{C}\right)\end{array}$ & $\begin{array}{c}\text { Textmax } \\
\left({ }^{\circ} \mathrm{C}\right)\end{array}$ & $\begin{array}{c}\text { Tintmax } \\
\left({ }^{\circ} \mathrm{C}\right)\end{array}$ & $\begin{array}{c}\text { Tdfmax } \\
\left({ }^{\circ} \mathrm{C}\right)\end{array}$ \\
\hline 1 & 31.3 & 45.5 & 32.0 & 54.0 & 22.0 \\
2 & 27.3 & 34.4 & 29.0 & 40.0 & 11.0 \\
3 & 30.9 & 43.4 & 39.0 & 50.5 & 19.0 \\
4 & 31.8 & 46.7 & 36.0 & 58.0 & 22.0 \\
5 & 27.1 & 34.5 & 30.0 & 42.0 & 12.0 \\
6 & 31.9 & 46.8 & 36.0 & 55.0 & 21.0 \\
7 & 33.4 & 47.8 & 37.0 & 57.0 & 21.0 \\
\hline
\end{tabular}

Figure 5 shows the daily distillate yield for the seven days. The maximum volume of potable water produced within the project period was $0.115 \mathrm{~m}^{3}$ and this occurred on the 3rd day. Total volume of pure water produced within the seven days was $0.63 \mathrm{~m}^{3}$. Hence our $0.16 \mathrm{~m}^{2}$ distillation kit was able to produce an average of $0.09 \mathrm{~m}^{3}$ of potable water per day. It was also observed that a comparable high volume of distilled water usually collects towards evening as atmospheric temperature decreases.

A comparison of daily efficiencies is shown in Figure 6. The highest efficiency of $9.3 \%$ was obtained on Day 1 , while the minimum efficiency of $6.3 \%$ was recorded on the 2 nd day. The average efficiency of the $0.16 \mathrm{~m}^{2}$ slanting-type solar water distillation kit was $7.7 \%$.

\section{CONCLUSION}

There is an urgent need for potable water in many countries of the world including Nigeria. A slanting-type solar water distillation (SSWD) system was successfully fabricated and tested under the actual environmental conditions of Imo State University, Owerri, Nigeria. The system consists of four major components; a wooden basin (heating chamber), an absorber surface (black liner), a slanting glass roof, and a condensate channel.

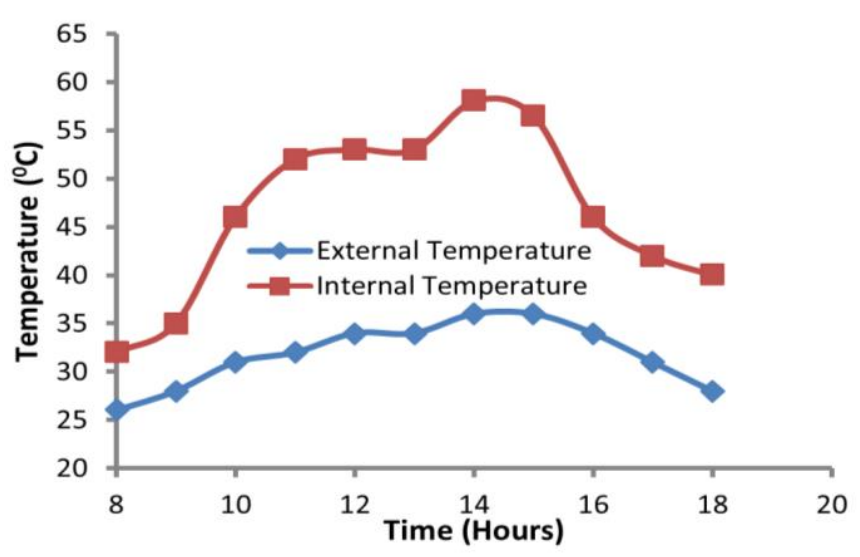

Figure 4: Hourly variation of external and internal temperatures (Day 4)

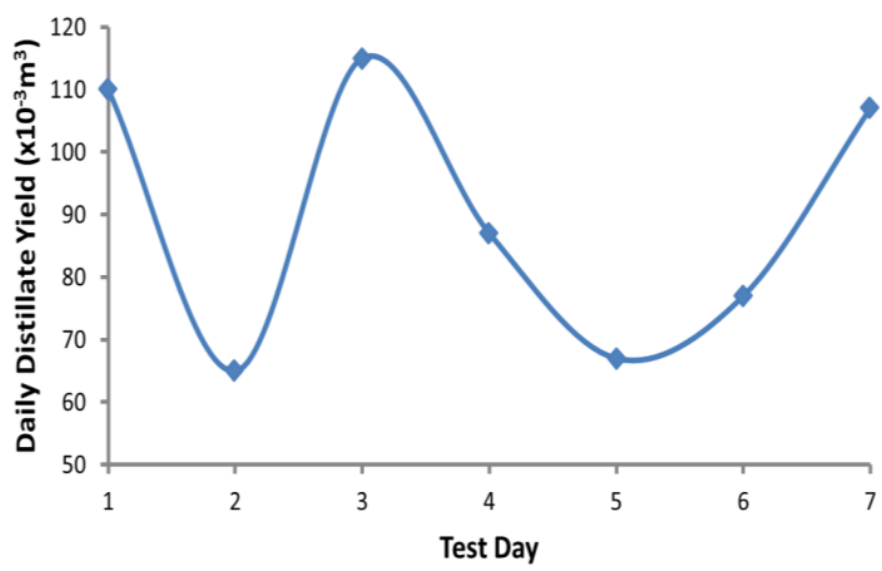

Figure 5: Daily distillate yields for the period of the project

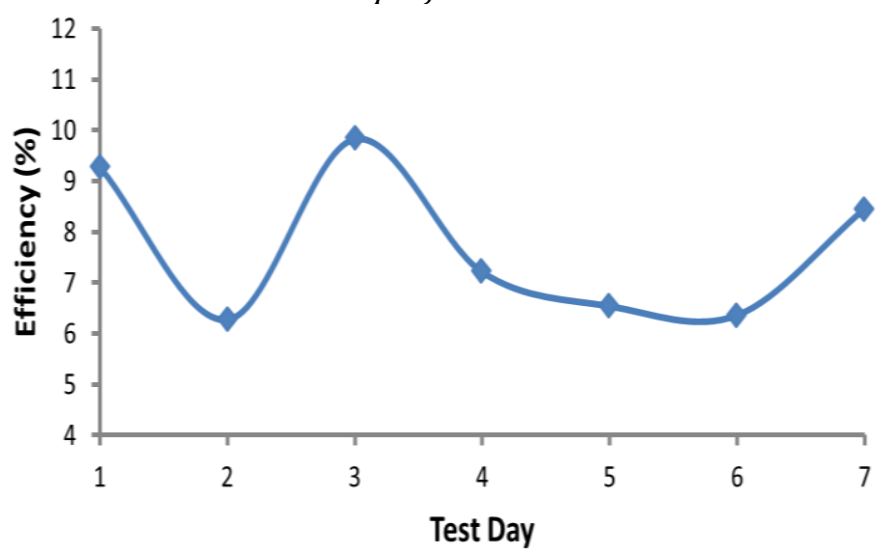

Figure 6: Comparison of daily efficiencies

The daily distillate yield ranged from $0.07 \mathrm{~m}^{3}$ to $0.1 \mathrm{~m}^{3}$, while the daily efficiency varied from $6.4 \%$ to $9.3 \%$. Actually, the average daily yield $\left(0.09 \mathrm{~m}^{3}\right)$ is small when compared to daily need of drinking water. The overall efficiency of the $0.16 \mathrm{~m}^{2}$ SSWD kit is $7.7 \%$, and this is small like many other solar installations. However, the volume of distilled water or the efficiency of the system 
can be increased by fabricating a SSWD of larger surface area. Also, since the SSWD can be fabricated with locally and readily available materials, one can fabricate a good number of the kit to meet daily demand of potable water. Like every other solar installation, SSWD system is environment friendly and has low operating and maintenance costs.

\section{REFERENCES}

[1] Mehta, A., Vyas, A., Bodar, N. and Lathiya, D. "Design of solar distillation system", International Journal of Advanced Science and Technology, Vol.29, pp 67-74. 2011.

[2] Bhattacharyya, A. "Solar stills for desalination of water in rural households, International Journal of Environment and Sustainability," Vol. 2, Number 1, pp 21-30. 2013,

[3] Ozuomba, J.O., Edebeatu, C. C., Opara, F.M., Udoye, M.C. and Okonkwo, N. A. "A possibility to combat the intake of poor quality drinking water by Nigerians using a locally fabricated solar water distillation kit", Advances in Applied Science Research, Vol. 3, Number 4, pp 2204-2211. 2012.

[4] Unnisa, S. A. and Khalilullah, M. "Impact of industrial pollution on ground and surface water quality in the Kattedan industrial area", Journal of Indian Association for Environmental Management, Vol. 31, pp 77-80. 2004.

[5] Shraddha, S., Rakesh, V., Savita, D. and Praveen, J. "Evaluation of water quality of Narmada river with reference to physico-chemical parameters at Hoshangabad city, MP, India", Research Journal of Chemical Sciences, Vol. 1, Number 3, pp 40-48. 2011.

[6] Tenthani, C., Madhlopa, A. and Kimambo, C. Z. "Improved solar still for water purification", Journal of Sustainable Energy and Environment, Vol. 3, pp 111-113. 2012.

[7] Sehar, S., Naz, I., Ali, M. I. and Ahmed, S. "Monitoring of physico-chemical and microbial analysis of underground water samples of District Kallar Syedan, Rawalpindi - Pakistan", Research Journal of Chemical Sciences, Vol. 1, Number 8, 2011, pp 24-30.

[8] Gupta, B., Mandraha, T. K., Edla, P. J. and Pandya, M. "Therma modelling and efficiency of solar water distillation: A review", American Journal of Engineering Research, Vol. 2, Number 12, pp 203213. 2013.

[9] Peter, K. A., Opsahl, S. P. and Chanton, J. P. “Tracking anthropogenic inputs using caffeine, indicator bacteria and nutrients in rural freshwater and urban marine systems", Environmental Science and Technology, Vol. 40, pp 7616-7622. 2006.

[10] Chessbrough, M. Medical Laboratory Manual for Tropical Countries Volume II, University Press, Cambridge, 1994.

[11] Haider, T., Sommer, R., Siegfried, E.P., Pribil, W., Caha, A. and Kundi, M. "Genotype response of Austrian disinfection conditions of three different bioassays", Water Res., Vol. 36, Number 1, pp 25-32. 2002,

[12] Medugu, D. W. and Ndatuwong, L.G. "Theoretical analysis of water distillation using solar still, International Journal of Physical Sciences, Vol. 4, Number 11, pp 705-712. 2009.

[13] Chen, T. and Ho, C. "Immediate assisted solar direct contact membrane distillation in saline water desalination", Journal of Membrane Science, Vol. 358, pp 122-130. 2010.

[14] Aybar, H. S., Egelioglu, F. and Atikol, U. "An experimental study on an inclined solar water distillation system", Desalination, Vol. 180, pp 285289. 2005.

[15] Tripathi R. and Tiwari G. N . "Effect of water depth on internal heat and mass transfer for active solar distillation", Desalination, Vol. 173, 187-200. 2005.

[16] Ibrahim, A. A., Dauda, M., Pam, G. Y. and Obada, D. O., "Design, construction and performance comparison of two solar stills having different absorber design", Nigerian Journal of Technology, Vol. 34, Number 4, pp 761-767. 2015.

[17] Rodriguez, L. G., Palmero-Marreroa, A. I. and Gbmez-Camachob, C. "Comparison of solar thermal technologies for applications in seawater desalination", Desalination, Vol. 142, pp 135-142. 2002.

[18] Reali, M. "Solar barometric distillation for seawater desalinating Part II: Analysis of one-stage and two stage distillation technologies", Desalination, Vol. 190, pp 29-42. 2006.

[19] Xuyun, W., Lin, Z., Huajian, Y. and Huanlin, C. "Feasibility research of potable water production via solar-heated hollow fibre membrane distillation system", Desalination, Vol. 247,pp 403-411. 2009.

[20] Shankar, P. and Kumar, S. "Solar distillation - A parametric review", VSRD International Journal of Mechanical, Automobile and Production Engineering, Vol. 2, Number 1, , pp 17-33. 2012. 